\title{
RANCANG BANGUN APLIKASI MEDIA PEMBELAJARAN MENGENAL NAMA HEWAN DALAM DUA BAHASA BERBASIS ANDROID MENGGUNAKAN THUNKABLE
}

\author{
Goldie Gunadi \\ Program Studi Teknik Informatika STMIK Widuri Jakarta, Indonesia \\ E-mail : send2goldie@gmail.com
}

Submission date: $2020-05-28$

Accepted date: 2020-06-09

\begin{abstract}
With the rapid development of Android-based smartphone technology devices, many learning media applications for multimedia-based children have been developed, the aim of which is to increase children's interest and motivation to learn in order to better receive the learning material provided. In this study, an Android-based animal recognition application design was carried out using two languages namely Indonesian and English. The design process is done using UML modeling, while the process of making an application is done using a tool that is Thunkable. With Thunkable the process of making applications becomes easier, faster and efficient. To ensure that every functional application runs properly in accordance with expectations, Black-Box testing is performed. The results of this study are an Android application that uses a variety of multimedia resources such as images, audio (sound) and video, as well as having an attractive and easy to use interface so that it can help early childhood children learn the material presented in this application.
\end{abstract}

Keywords: Learning, Children, Animals, Android, Thunkable, Multimedia

\begin{abstract}
ABSTRAK
Dengan adanya perkembangan perangkat teknologi smartphone berbasis Android yang sangat pesat, banyak sekali aplikasi-aplikasi media pembelajaran untuk anak-anak berbasis multimedia yang dikembangkan, tujuannya adalah untuk meningkatkan minat dan motivasi belajar anak agar dapat menerima materi pembelajaran yang diberikan dengan lebih baik. Dalam penelitian ini, dilakukan rancang bangun aplikasi pengenalan hewan berbasis Android dengan menggunakan dua bahasa yaitu Indonesia dan Inggris. Proses perancangan dilakukan menggunakan pemodelan UML, sedangkan proses pembuatan aplikasi dilakukan dengan menggunakan sebuah alat bantu yaitu Thunkable. Dengan Thunkable proses pembuatan aplikasi menjadi lebih mudah, cepat dan efisien. Untuk memastikan setiap fungsional aplikasi berjalan dengan baik sesuai dengan harapan dilakukan pengujian Black-Box. Hasil dari penelitian ini adalah sebuah aplikasi Android yang menggunakan berbagai sumber daya multimedia seperti gambar, audio (suara) dan video, serta memiliki tampilan antarmuka yang menarik dan mudah digunakan sehingga dapat membantu anak-anak usia dini mempelajari materi-materi yang disajikan pada aplikasi ini.
\end{abstract}

Kata Kunci: Pembelajaran, Anak, Hewan, Android, Thunkable, Multimedia

\section{PENDAHULUAN}

Perkembangan teknologi informasi mengalami perkembangan yang sangat pesat. Perkembangan ini telah mengubah paradigma masyarakat dalam mencari dan mendapatkan informasi, tidak hanya melalui media konvensional seperti media cetak, radio dan televisi, namun juga dapat diperoleh dari berbagai sumber melalui teknologi jaringan internet. Bidang pendidikan merupakan salah satu bidang yang mendapat dampak yang cukup berarti dengan adanya perkembangan teknologi ini.

Pendidikan untuk anak-anak kelompok usia dini sangatlah penting. Menurut Undang - undang Sisdiknas tahun 2003, anak usia dini adalah anak yang 
berada pada rentan usia 0 - 6 tahun. Dengan adanya perkembangan teknologi informasi diharapkan dapat memberikan solusi pembelajaran yang efektif bagi anak-anak usia dini. Media pembelajaran berbasis multimedia mempunyai banyak keunggulan karena melibatkan hampir semua unsur indra. Penggunaan teknologi multimedia dapat mempermudah anak dalam belajar, waktu yang digunakan menjadi lebih efektif dan efisien serta dapat meningkatkan semangat dan motivasi belajar. Dengan motivasi yang meningkat maka prestasi anak di sekolah pun akan dapat diraih dengan lebih optimal (Surasmi, 2016).

Perangkat telepon pintar (smartphone) berbasis Android adalah media yang paling banyak digunakan saat ini untuk menyajikan berbagai aplikasi multimedia. Android adalah sistem operasi berbasis Linux yang dirancang untuk perangkat bergerak layar sentuh seperti telepon pintar dan komputer tablet. Kode dengan sumber terbuka (open source) dan lisensi perizinan pada Android memungkinkan perangkat lunak untuk dimodifikasi secara bebas dan didistribusikan oleh para pembuat perangkat, operator nirkabel, dan pengembang aplikasi (Open Handset Alliance, 2009).

Latar belakang masalah dari penelitian ini adalah diperlukannya sebuah aplikasi multimedia pembelajaran berbasis Android, yang dapat membantu anak-anak usia dini mengenal nama-nama hewan dalam dua bahasa yakni bahasa Indonesia dan bahasa Inggris. Untuk membuat aplikasi Android yang baik secara efisien dan efektif, diperlukan sebuah alat bantu pengembangan aplikasi Android berupa perangkat lunak yang memiliki fitur lengkap, mudah digunakan dan tidak memerlukan sumber daya serta biaya yang besar.

Tujuan dari penelitian ini adalah merancang dan membangun sebuah aplikasi multimedia pembelajaran berbasis Android untuk membantu anak usia dini mengenal nama-nama hewan dalam dua bahasa, yakni bahasa Inggris dan Indonesia dengan menggunakan alat bantu perangkat lunak pengembang aplikasi yaitu Thunkable.

Penelitian dari Indri Ayuningtyas, Muhammad Arief Fadhilah dan Rita Wahyuni Arifin dengan judul Media Pembelajaran Mengenal Hewan Dalam Bahasa Inggris Berbasis Multimedia Interaktif, dibuat media pembelajaran yang interaktif bagi siswa sekolah dasar kelas satu. Teknologi multimedia yang digunakan dalam penelitian adalah menggunakan aplikasi atau perangkat lunak Adobe Photoshop, Adobe Ilustrator dan Adobe Flash CS6. Teknik yang digunakan adalah membuatkan animasi pada tiap materi pengenalan nama hewan dalam bahasa inggris tujuannya agar siswa sekolah dasar kelas satu dapat mengingat dengan mudah nama-nama hewan karena ada suara dan lagu yang menarik (Ayuningtyas et al., 2018).

Pembaharuan dalam penelitian ini adalah aplikasi dibangun menggunakan perangkat lunak Thunkable. Thunkable merupakan aplikasi web yang dapat digunakan untuk membuat aplikasi smartphone dengan sistem operasi Android ataupun iOS. Perancangan aplikasi Android ataupun iOS pada Thunkable menggunakan konsep pemrograman visual yang sifatnya drag and drop. Bahasa pemrograman visual yang digunakan adalah Scratch (Raharjo, 2019). Aplikasi yang dibuat juga menyajikan suara audio serta visualisasi setiap hewan dalam bentuk gambar dan video.

Hasil dari penelitian ini dapat menghasilkan sebuah solusi alternatif dalam bentuk aplikasi media pembelajaran berbasis Android dengan tampilan antarmuka yang menarik dan mudah digunakan, untuk meningkatkan semangat dan motivasi belajar anakanak usia dini yang kemudian dapat berdampak kepada peningkatan prestasi belajar di sekolah. Aplikasi yang dihasilkan diharapkan dapat menjadi pelengkap dari berbagai aplikasi sejenis yang telah dibuat sebelumnya.

\section{METODE PENELITIAN}

Metode pengumpulan data yang digunakan dalam penelitian ini adalah :

1. Studi pustaka, dimana pengumpulan data dilakukan dengan cara meneliti sejumlah literatur atau referensi yang sekiranya dapat membantu dan mendukung kegiatan penelitian yang dilakukan.

2. Observasi, yang dilakukan melalui pengamatan terhadap sejumlah aplikasi-aplikasi Android yang sejenis dengan aplikasi media pembelajaran yang akan dibuat dalam penelitian ini.

Metodologi yang digunakan dalam pengembangan aplikasi menggunakan metode Waterfall, meliputi kegiatan-kegiatan sebagai berikut:

1. Analisis Kebutuhan.

Mengidentifikasi kebutuhan kebutuhan pengguna serta kebutuhan penelitian dalam bentuk perangkat keras maupun perangkat lunak.

2. Perancangan.

Tahapan perancangan berfokus pada dua atribut yang berbeda, seperti arsitekur perangkat lunak dan antar-muka pengguna. Proses perancangan yaitu upaya menerjemahkan kebutuhan pengguna menjadi sebuah perangkat lunak yang dapat dinilai kualitasnya sebelum pembuatan aplikasi. Proses perancangan 
dilakukan menggunakan teknik pemodelan Unified Modeling Language (UML).

Unified Modeling Language (UML) adalah bahasa untuk menspesifikasi, memvisualisasikan, serta mengonstruksi bangunan dasar sistem perangkat lunak, termasuk melibatkan pemodelan aturan-aturan bisnis (Fadallah \& Rosyida, 2018).

Adapun diagram UML yang digunakan pada penelitian ini adalah: Use Case Diagram, Activity Diagram dan Statechart Diagram.

3. Pengembangan

Proses pengembangan aplikasi Android media pembelajaran nama hewan menggunakan sebuah alat bantu perangkat lunak yaitu Thunkable.

4. Pengujian

Proses pengujian dilakukan untuk memastikan aplikasi yang telah sesuai dengan persyaratan spesifikasi kebutuhan fungsional yang telah ditentukan sebelumnya dengan menggunakan metode pengujian Black-Box (Black-Box Testing).

Black-Box Testing merupakan metode pengujian perangkat lunak yang meneliti fungsi (Functional Testing) dari aplikasi tanpa melihat ke dalam struktur internal atau kinerja aplikasi (Febiharsa et al., 2018).

\section{HASIL DAN PEMBAHASAN}

\section{Analisis Kebutuhan}

Kebutuhan pengguna terhadap aplikasi pengenalan nama hewan berbasis Android kebutuhan fungsional dan kebutuhan non fungsional.

Kebutuhan fungsional meliputi:

1. Aplikasi dapat menampilkan menu pembelajaran mengenai sejumlah hewan, yang meliputi: pengetahuan nama-nama hewan dalam dua bahasa yakni bahasa Indonesia dan bahasa Inggris, pengenalan gambar dan bunyi suara dari masing-masing hewan serta mempelajari tingkah laku dan perilaku hewan dalam bentuk video.

2. Aplikasi menyediakan fasilitas untuk mengevaluasi tingkat pemahaman pengguna sebagai hasil dari pembelajaran yang telah dilakukan. Proses evaluasi meliputi : latihan tebak gambar dan tebak suara hewan.

3. Aplikasi menyediakan fasilitas untuk menampilkan berbagai informasi dari program aplikasi, yaitu: nama program, versi, nama pengembang dan tanggal pembaharuan (update) aplikasi terakhir.
Kebutuhan non fungsional meliputi:

1. Aplikasi dapat dijalankan pada sistem operasi Android minimal versi 4.1 dan 4.3 Jelly Bean.

2. Aplikasi memiliki tampilan antar muka yang baik dan mudah digunakan oleh pengguna anak TK.

3. Aplikasi tidak membutuhkan sumber daya yang besar pada saat digunakan seperti kinerja processor, kapasitas RAM serta media penyimpanan pada perangkat yang digunakan.

4. Aplikasi dapat dijalankan secara off-line tanpa perlu terhubung ke jaringan internet.

Kebutuhan pengembang aplikasi meliputi kebutuhan perangkat keras, perangkat lunak dan koneksi jaringan.

Kebutuhan perangkat keras meliputi:

1. 1 (Satu) unit perangkat laptop/PC dengan spesifikasi minimum sebagai berikut:

a. Prosesor 1 gigahertz $(\mathrm{GHz})$

b. RAM 2 GB

c. Hard disk $250 \mathrm{~GB}$

d. Kartu Grafis kompatibilitas dengan DirectX 9 dan WDDM 1.0 driver

e. Resolusi tampilan layar $800 \times 600$

f. Speaker

2. 1 (Satu) unit perangkat smartphone berbasis Android dengan spesifikasi minimum sebagai berikut:
a. Prosesor quad-core $1,2 \mathrm{GHz}$
b. Sistem operasi Android 4.1 Jelly Bean
c. RAM $1 \mathrm{~GB}$
d. Memory $8 \mathrm{~GB}$
e. Layar 4 inch dengan resolusi $800 \times 480$

Kebutuhan perangkat lunak meliputi:

1. Sistem operasi Windows 7 64-bit

2. Aplikasi browser Google Chrome versi 81.0.4044.138 (Official Build) (64-bit)

3. Aplikasi online Thunkable: https://thunkable.com

4. Aplikasi online PIXLR: https://pixlr.com

5. Aplikasi online Audio Trimmer: https://audiotrimmer.com

Kebutuhan koneksi jaringan:

Koneksi jaringan internet dengan kecepatan ratarata download: 4 Mbps dan kecepatan rata-rata upload: 3 Mbps.

\section{Perancangan}

Modul Aplikasi

Modul aplikasi terdiri dari:

1. Modul Belajar Hewan: Menampilkan pilihan gambar hewan yang dapat dipilih untuk dapat 
mengetahui informasi lebih lanjut mengenai hewan tersebut.

2. Modul Tebak Gambar: Menyediakan latihan untuk evaluasi pengenalan pengguna terhadap gambar foto hewan.

3. Modul Tebak Suara: Menyediakan latihan untuk evaluasi pengenalan pengguna terhadap suara hewan.

4. Modul Informasi Aplikasi: Menampilkan informasi mengenai nama, versi, nama pembuat aplikasi dan tanggal pembaharuan (update) aplikasi terakhir.

Diagram Use Case

Digunakan untuk menggambarkan fungsional aplikasi yang dibuat.

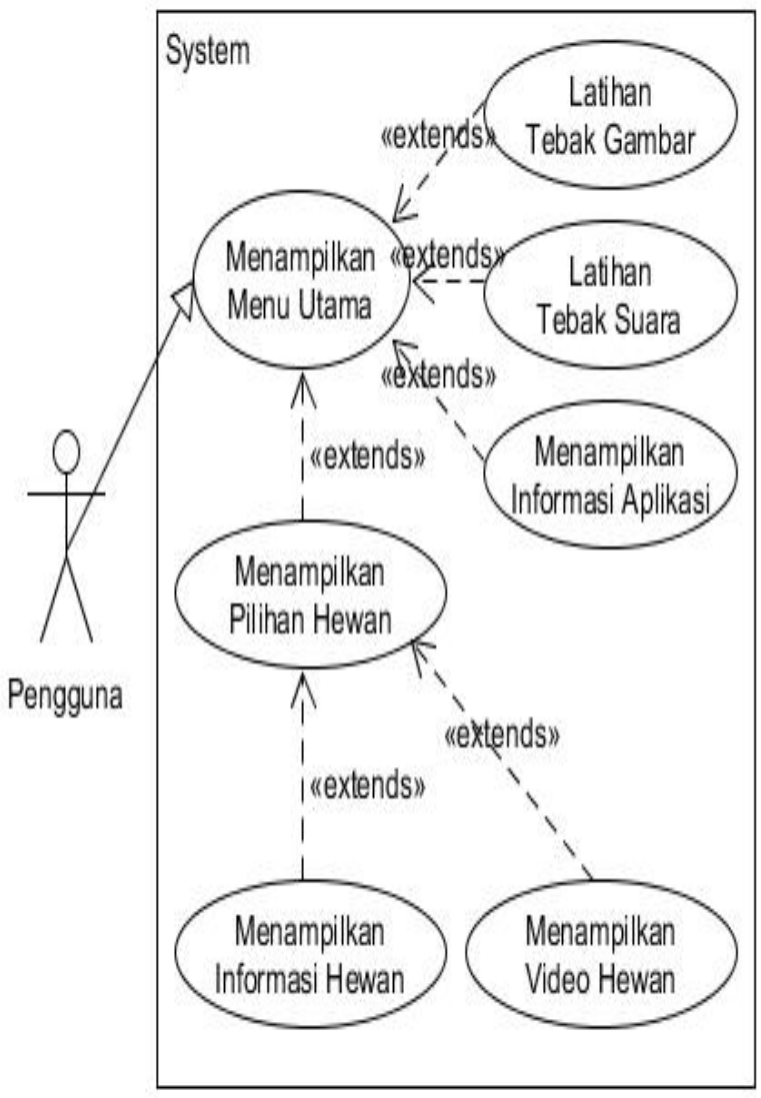

Sumber : (Gunadi, 2020)

Gambar 1. Diagram Use Case

Diagram Activity

Digunakan untuk menggambarkan kegiatan / aktivitas pengguna untuk setiap fungsional aplikasi. 1. Diagram Activity Belajar Hewan

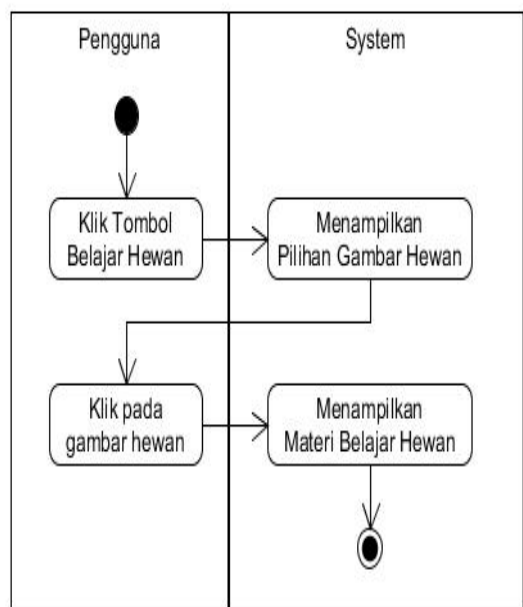

Sumber : (Gunadi, 2020)

Gambar 2. Diagram Activity Belajar Hewan

2. Diagram Activity Tebak Gambar/Tebak Suara
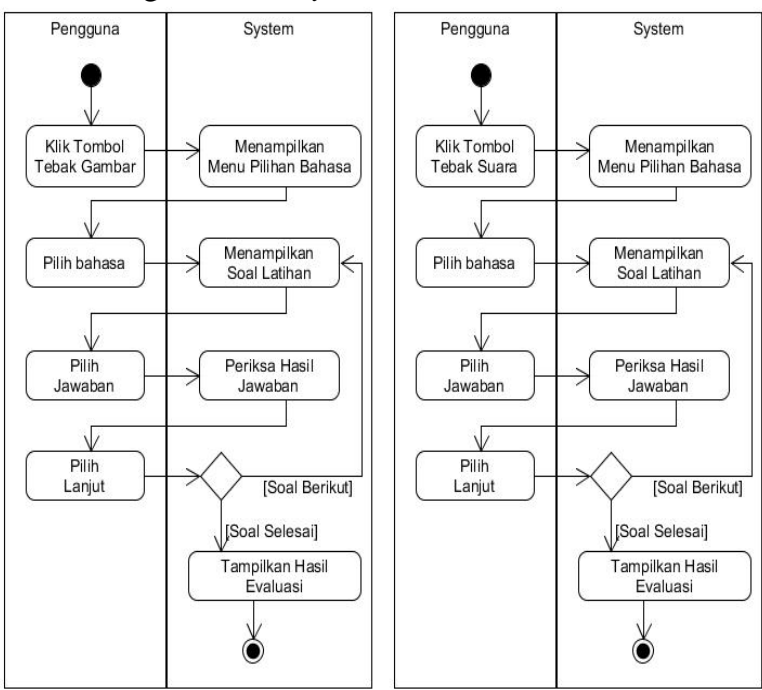

Sumber : (Gunadi, 2020)

Gambar 3. Diagram Activity Tebak Gambar dan Tebak Suara

3. Diagram Activity Informasi Aplikasi

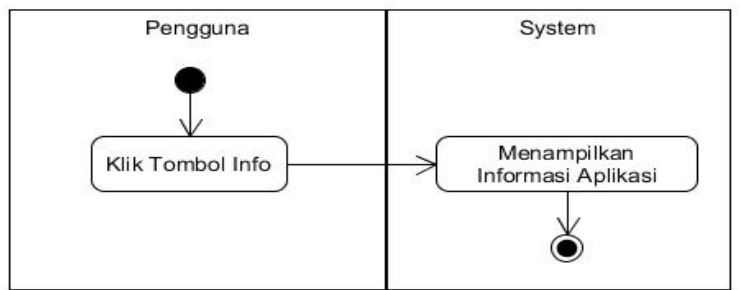

Sumber : (Gunadi, 2020)

Gambar 4. Diagram Activity Informasi Aplikasi 


\section{Diagram Statechart}

Digunakan untuk menggambarkan alur proses perpindahan status aplikasi. Status disini merupakan tampilan antar muka dari aplikasi yang dibuat.

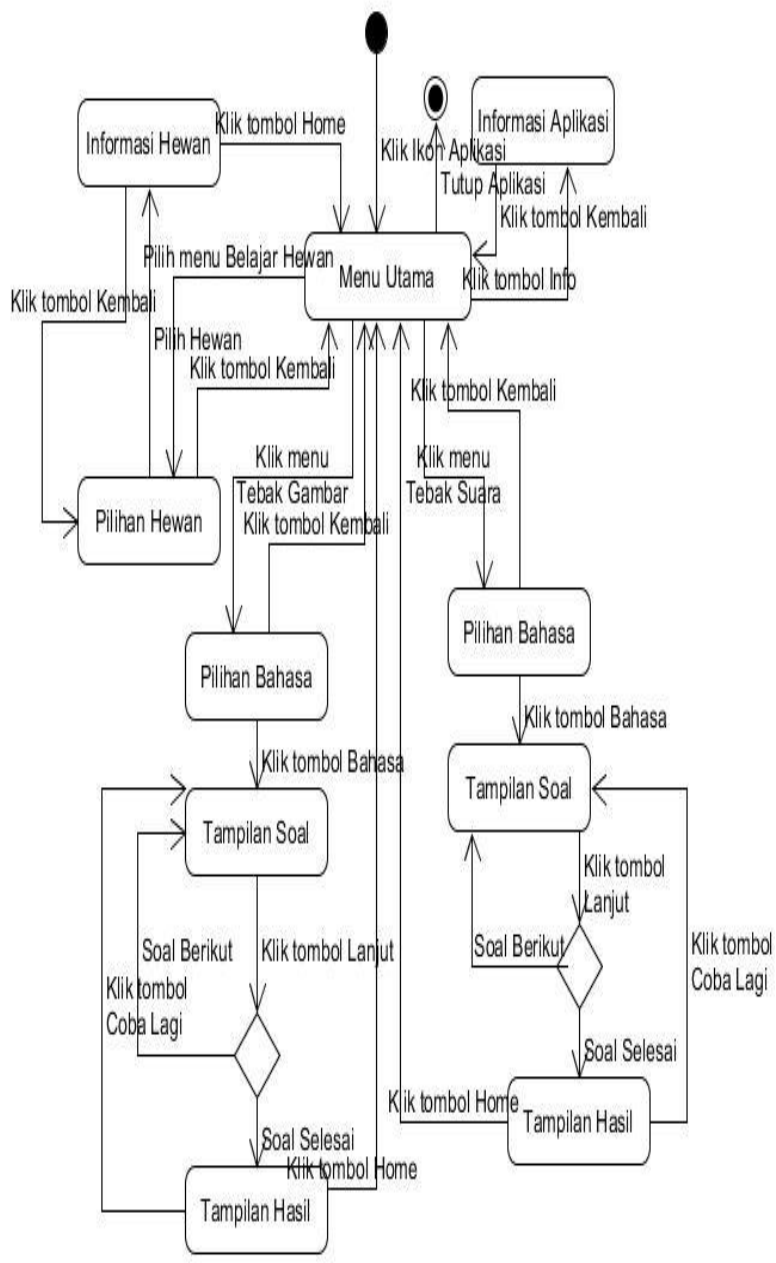

Sumber : (Gunadi, 2020)

Gambar 5. Diagram Statechart

\section{Pembuatan Aplikasi}

Proses pembuatan aplikasi menggunakan Thunkable meliputi proses pembuatan antarmuka dan pembuatan control/kendali program dari setiap komponen antar muka. Berikut ini adalah tampilan antarmuka aplikasi:

1. Tampilan Menu Utama

Pada tampilan ini disajikan sejumlah tombol: Tombol Info, Belajar Hewan, Tebak Gambar dan Tebak Suara yang digunakan untuk mengakses modul-modul aplikasi yang tersedia.

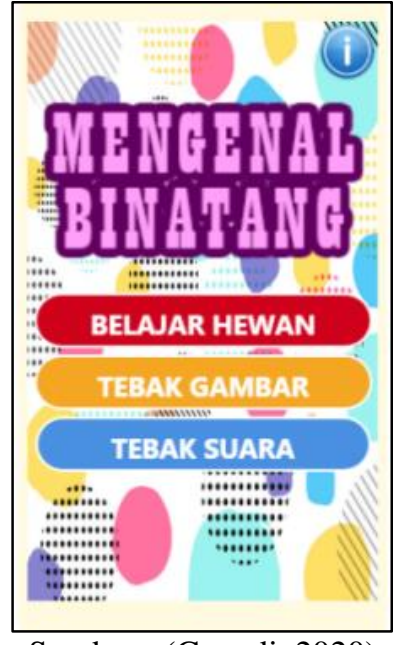

Sumber : (Gunadi, 2020)

Gambar 6. Tampilan Menu Utama

2. Tampilan Pilihan Hewan

Menampilkan tombol gambar-gambar hewan yang dapat dipilih pengguna untuk dipelajari.

Terdapat juga tombol Back untuk kembali ke tampilan sebelumnya dan tombol Home untuk ke Menu Utama.

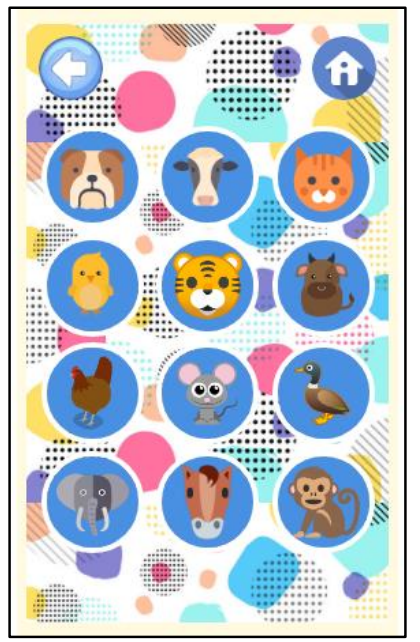

Sumber : (Gunadi, 2020)

Gambar 7. Tampilan Menu Utama

3. Tampilan Informasi Hewan

Pada tampilan ini terdapat komponen switch yang digunakan untuk memilih bahasa yang diinginkan. Di sebelah pilihan bahasa terdapat tombol Sound yang digunakan untuk mendengarkan ejaan nama hewan. Di bagian bawah gambar hewan terdapat tombol Audio untuk mendengarkan suara hewan dan tombol Video untuk melihat video hewan. 
Pada Gambar 8 adalah contoh tampilan informasi dan video hewan pada saat memilih tombol hewan kucing.

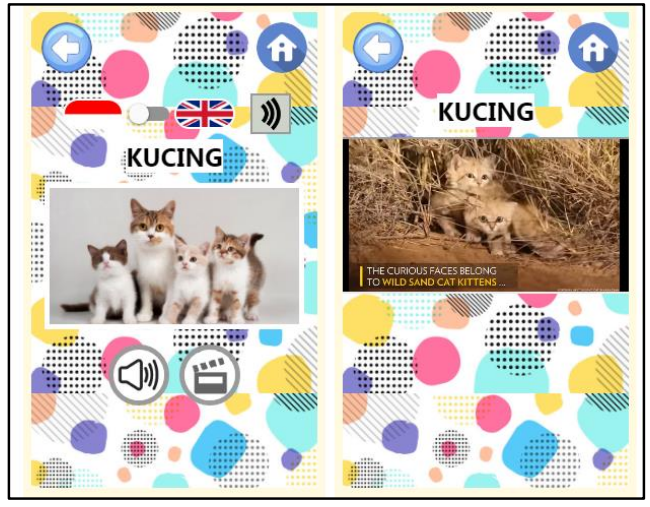

Sumber : (Gunadi, 2020)

Gambar 8. Tampilan Informasi dan Video Hewan

4. Tampilan Pilih Bahasa Latihan

Pada tampilan pilih bahasa dalam menu Tebak Gambar dan Tebak Suara masing-masing terdapat 2 tombol untuk memilih bahasa yang diinginkan.

Pada Gambar 9 adalah contoh tampilan pilihan bahasa pada modul Tebak Gambar dan Tebak Suara.

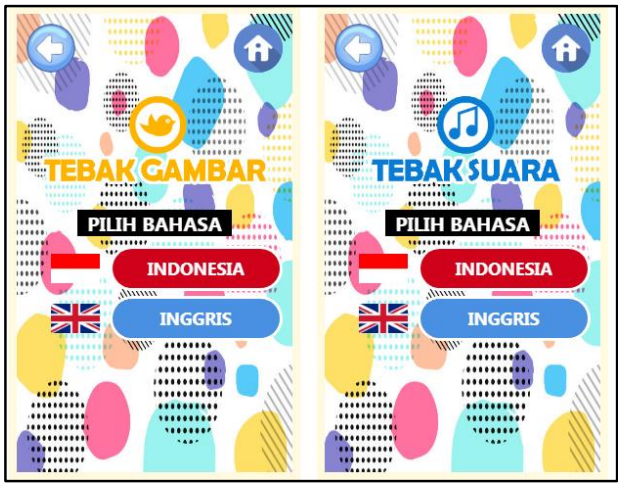

Sumber : (Gunadi, 2020)

Gambar 9. Tampilan Pilih Bahasa Latihan

5. Tampilan Soal Latihan Tebak Gambar

Pada tampilan soal tebak gambar terdapat sebuah gambar hewan. Di bagian bawah gambar hewan terdapat tombol-tombol bertuliskan nama hewan yang dapat dipilih sesuai dengan tampilan gambar. Nama hewan dapat berupa bahasa Indoensia atau Inggris sesuai dengan pilihan bahasa yang telah ditentukan sebelumnya.

Pada Gambar 10 adalah contoh tampilan soal Tebak Gambar dengan pilihan jawaban bahasa Indonesia dan Inggris.

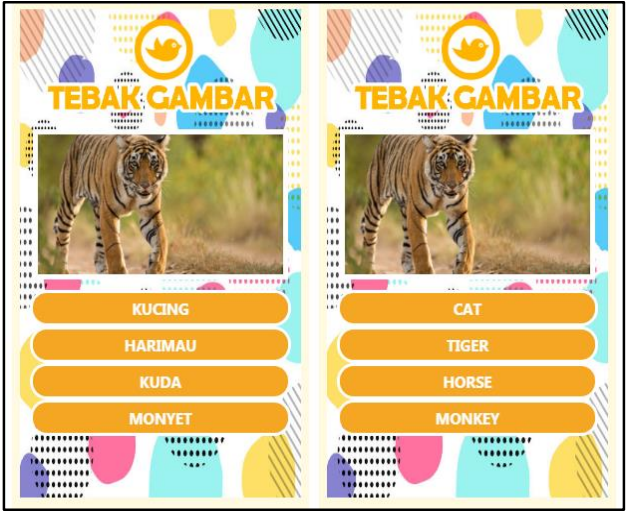

Sumber : (Gunadi, 2020)

Gambar 10. Tampilan Soal Latihan Tebak Gambar

6. Tampilan Soal Latihan Tebak Suara.

Pada tampilan soal tebak gambar terdapat sebuah tombol Sound untuk mendengarkan suara hewan. Di bagian bawah tombol Sound terdapat tomboltombol bertuliskan nama hewan yang dapat dipilih sesuai dengan bunyi suara yang terdengar. Nama hewan dapat berupa bahasa Indoensia atau Inggris sesuai dengan pilihan bahasa yang telah ditentukan sebelumnya.

Pada Gambar 11 adalah contoh tampilan soal Tebak Suara dengan pilihan jawaban bahasa Indonesia dan Inggris.

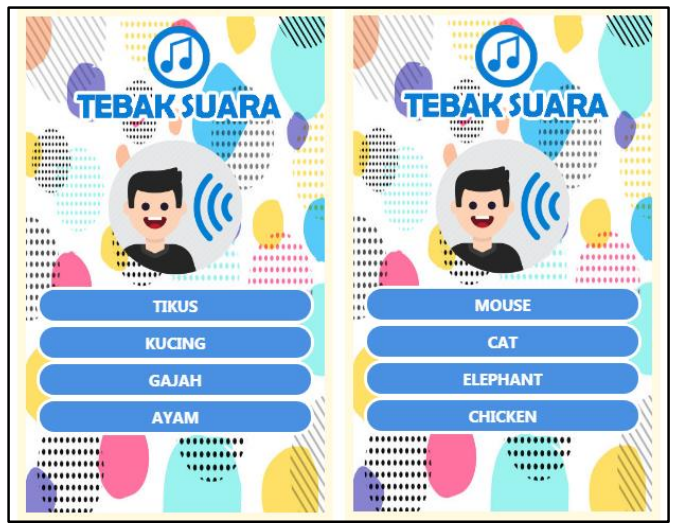

Sumber : (Gunadi, 2020)

Gambar 11. Tampilan Soal Latihan Tebak Gambar

7. Tampilan Hasil Latihan

Tampilan hasil latihan menampilan nilai hasil evaluasi yang diwakili oleh gambar bintang sebanyak 1 hingga 5. Dibawah gambar bintang terdapat informasi jumlah jawaban yang benar dan salah. Pada bagian paling bawah terdapat tombol Coba Lagi untuk memulai kembali latihan yang sama.

Pada Gambar 12 adalah contoh tampilan hasil evaluasi Tebak Suara dan Tebak Gambar. 


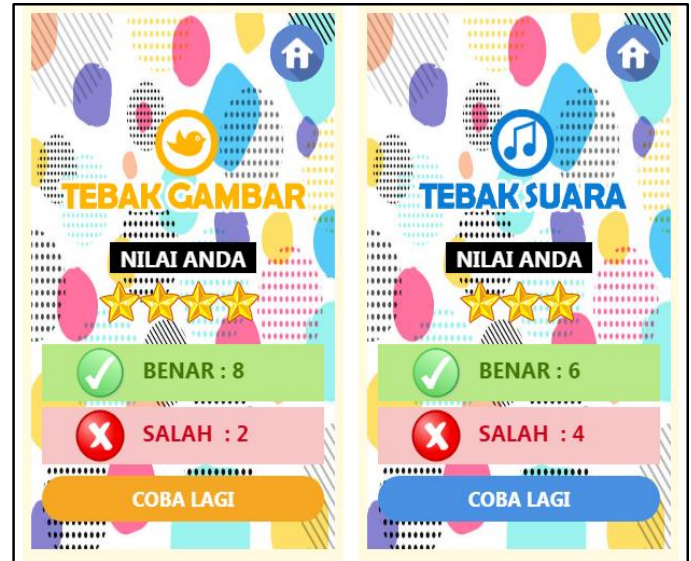

Sumber : (Gunadi, 2020)

Gambar 12. Tampilan Hasil Latihan

8. Tampilan Informasi Aplikasi

Menampilkan informasi aplikasi yang terdiri dari: nama aplikasi, versi, nama pembuat aplikasi serta tanggal pembaharuan aplikasi terakhir.

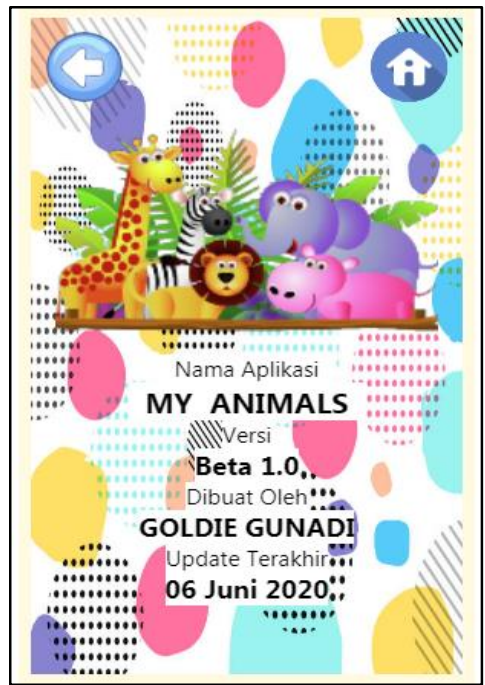

Sumber : (Gunadi, 2020)

Gambar 13. Tampilan Informasi Aplikasi

\section{Pengujian}

Proses pengujian dilakukan menggunkan metode Black-Box untuk memastikan setiap proses dari setiap antarmuka aplikasi berjalan dengan baik. dilakukan:

Berikut adalah hasil dari pengujian yang

\section{Pengujian Proses Belajar Hewan}

Tabel 1. Hasil Pengujian Proses Belajar Hewan

\begin{tabular}{llcl}
\hline $\begin{array}{c}\text { Kegiatan } \\
\text { Pengujian }\end{array}$ & Antarmuka & $\begin{array}{c}\text { Hasil } \\
\text { Pengujian }\end{array}$ & Kesimpulan \\
\hline Klik & Menu & Menampilkan & Diterima \\
tombol & Utama & halaman Pilih & \\
\hline
\end{tabular}

\begin{tabular}{|c|c|c|c|}
\hline $\begin{array}{l}\text { Belajar } \\
\text { Hewan }\end{array}$ & & Hewan & \\
\hline $\begin{array}{l}\text { Klik salah } \\
\text { satu } \\
\text { tombol } \\
\text { bergambar } \\
\text { hewan }\end{array}$ & Pilih Hewan & $\begin{array}{l}\text { Menampilkan } \\
\text { halaman } \\
\text { Informasi } \\
\text { Hewan sesuai } \\
\text { dengan gambar } \\
\text { hewan yang } \\
\text { dipilih }\end{array}$ & Diterima \\
\hline $\begin{array}{l}\text { Rubah } \\
\text { posisi } \\
\text { switch } \\
\text { untuk } \\
\text { memilih } \\
\text { bahasa } \\
\end{array}$ & $\begin{array}{l}\text { Informasi } \\
\text { Hewan }\end{array}$ & $\begin{array}{l}\text { Menampilkan } \\
\text { nama hewan } \\
\text { dalam bahasa } \\
\text { yang dipilih }\end{array}$ & Diterima \\
\hline $\begin{array}{l}\text { Klik } \\
\text { tombol } \\
\text { Sound }\end{array}$ & $\begin{array}{l}\text { Informasi } \\
\text { Hewan }\end{array}$ & $\begin{array}{l}\text { Terdengar } \\
\text { suara ejaan } \\
\text { nama hewan }\end{array}$ & Diterima \\
\hline $\begin{array}{l}\text { Klik } \\
\text { tombol } \\
\text { Audio } \\
\end{array}$ & $\begin{array}{l}\text { Informasi } \\
\text { Hewan }\end{array}$ & $\begin{array}{l}\text { Terdengar } \\
\text { suara hewan }\end{array}$ & Diterima \\
\hline $\begin{array}{l}\text { Klik } \\
\text { tombol } \\
\text { Video }\end{array}$ & $\begin{array}{l}\text { Informasi } \\
\text { Hewan }\end{array}$ & $\begin{array}{l}\text { Menampilkan } \\
\text { halaman Video } \\
\text { Hewan }\end{array}$ & Diterima \\
\hline
\end{tabular}

2. Pengujian Proses Latihan Tebak Gambar

Tabel 2. Hasil Pengujian Proses Latihan Tebak Gambar

\begin{tabular}{|c|c|c|c|}
\hline $\begin{array}{l}\text { Kegiatan } \\
\text { Pengujian }\end{array}$ & Antarmuka & $\begin{array}{c}\text { Hasil } \\
\text { Pengujian }\end{array}$ & Kesimpulan \\
\hline $\begin{array}{l}\text { Klik } \\
\text { tombol } \\
\text { Tebak } \\
\text { Gambar }\end{array}$ & $\begin{array}{l}\text { Menu } \\
\text { Utama }\end{array}$ & $\begin{array}{l}\text { Menampilkan } \\
\text { halaman Pilih } \\
\text { Bahasa Tebak } \\
\text { Gambar }\end{array}$ & Diterima \\
\hline $\begin{array}{l}\text { Klik } \\
\text { tombol } \\
\text { bahasa } \\
\text { yang } \\
\text { diinginkan: } \\
\text { Indonesia } \\
\text { atau } \\
\text { Inggris }\end{array}$ & $\begin{array}{l}\text { Pilih } \\
\text { Bahasa } \\
\text { Tebak } \\
\text { Gambar }\end{array}$ & $\begin{array}{l}\text { Menampilkan } \\
\text { soal tebak } \\
\text { gambar } \\
\text { beserta tombol } \\
\text { pilihan nama } \\
\text { hewan dalam } \\
\text { bahasa terpilih }\end{array}$ & Diterima \\
\hline $\begin{array}{l}\text { Klik salah } \\
\text { satu } \\
\text { tombol } \\
\text { nama } \\
\text { hewan } \\
\text { untuk } \\
\text { menjawab } \\
\text { soal }\end{array}$ & $\begin{array}{l}\text { Soal Tebak } \\
\text { Gambar }\end{array}$ & $\begin{array}{l}\text { Bila jawaban } \\
\text { salah maka } \\
\text { tombol akan } \\
\text { berwarna } \\
\text { merah dan } \\
\text { tombol } \\
\text { jawaban yang } \\
\text { benar } \\
\text { berwarna } \\
\text { hijau. } \\
\text { Muncul } \\
\text { tombol Lanjut }\end{array}$ & Diterima \\
\hline $\begin{array}{l}\text { Klik } \\
\text { tombol } \\
\text { Lanjut }\end{array}$ & $\begin{array}{l}\text { Soal Tebak } \\
\text { Gambar }\end{array}$ & $\begin{array}{l}\text { Menampilkan } \\
\text { soal } \\
\text { berikutnya. } \\
\text { Bila sudah } \\
\text { selesai akan } \\
\text { ditampilkan }\end{array}$ & Diterima \\
\hline
\end{tabular}




\begin{tabular}{ll}
\hline Hasil Evaluasi \\
Tebak \\
Gambar. \\
Pada hasil \\
evaluasi \\
terdapat \\
informasi hasil \\
dari jawaban \\
soal latihan.
\end{tabular}

Sumber : (Gunadi, 2020)

3. Pengujian Proses Latihan Tebak Suara

Tabel 3. Hasil Pengujian Proses Latihan Tebak Suara

\begin{tabular}{|c|c|c|c|}
\hline $\begin{array}{c}\text { Kegiatan } \\
\text { Pengujian }\end{array}$ & Antarmuka & $\begin{array}{c}\text { Hasil } \\
\text { Pengujian }\end{array}$ & Kesimpulan \\
\hline $\begin{array}{l}\text { Klik } \\
\text { tombol } \\
\text { Tebak } \\
\text { Suara }\end{array}$ & $\begin{array}{l}\text { Menu } \\
\text { Utama }\end{array}$ & $\begin{array}{l}\text { Menampilkan } \\
\text { halaman Pilih } \\
\text { Bahasa Tebak } \\
\text { Suara }\end{array}$ & Diterima \\
\hline $\begin{array}{l}\text { Klik } \\
\text { tombol } \\
\text { bahasa } \\
\text { yang } \\
\text { diinginkan } \\
\text { : Indonesia } \\
\text { atau } \\
\text { Inggris } \\
\end{array}$ & $\begin{array}{l}\text { Pilih } \\
\text { Bahasa } \\
\text { Tebak } \\
\text { Suara }\end{array}$ & $\begin{array}{l}\text { Menampilkan } \\
\text { soal tebak } \\
\text { suara beserta } \\
\text { tombol pilihan } \\
\text { nama hewan } \\
\text { dalam bahasa } \\
\text { terpilih }\end{array}$ & Diterima \\
\hline $\begin{array}{l}\text { Klik } \\
\text { tombol } \\
\text { Sound }\end{array}$ & $\begin{array}{l}\text { Soal Tebak } \\
\text { Suara }\end{array}$ & $\begin{array}{l}\text { Terdengar } \\
\text { suara hewan }\end{array}$ & Diterima \\
\hline $\begin{array}{l}\text { Klik salah } \\
\text { satu } \\
\text { tombol } \\
\text { nama } \\
\text { hewan } \\
\text { untuk } \\
\text { menjawab } \\
\text { soal }\end{array}$ & $\begin{array}{l}\text { Soal Tebak } \\
\text { Suara }\end{array}$ & $\begin{array}{l}\text { Bila jawaban } \\
\text { salah maka } \\
\text { tombol akan } \\
\text { berwarna } \\
\text { merah dan } \\
\text { tombol } \\
\text { jawaban yang } \\
\text { benar } \\
\text { berwarna } \\
\text { hijau. } \\
\text { Muncul } \\
\text { tombol Lanjut }\end{array}$ & Diterima \\
\hline $\begin{array}{l}\text { Klik } \\
\text { tombol } \\
\text { Lanjut }\end{array}$ & $\begin{array}{l}\text { Soal Tebak } \\
\text { Suara }\end{array}$ & $\begin{array}{l}\text { Menampilkan } \\
\text { soal } \\
\text { berikutnya. } \\
\text { Bila sudah } \\
\text { selesai akan } \\
\text { ditampilkan } \\
\text { Hasil Evaluasi } \\
\text { Tebak Suara. } \\
\text { Pada hasil } \\
\text { evaluasi } \\
\text { terdapat } \\
\text { informasi hasil } \\
\text { dari jawaban } \\
\text { soal latihan. }\end{array}$ & Diterima \\
\hline
\end{tabular}

Sumber : (Gunadi, 2020)

\section{KESIMPULAN}

Dari penelitian yang dilakukan ini dapat diambil kesimpulan bahwa aplikasi pembelajaran nama hewan berbasis Android ini dapat digunakan sebagai salah satu alternatif untuk membantu anak usia dini ( 6 bulan-2 tahun) mengenal nama-nama hewan dalam dua bahasa, yakni bahasa Inggris dan Indonesia. Melalui aplikasi ini, seorang anak dapat mengenal nama-nama hewan dalam bahasa Indonesia dan Inggris melalui gambar foto, suara serta visualisasi dalam bentuk video.

Penggunaan perangkat lunak Thunkable sebagai alat bantu dalam proses pengembangan aplikasi media pembelajaran Android ini dengan berbagai fitur yang disediakan menjadikan proses pembuatan aplikasi menjadi lebih cepat, mudah dan efisien.

\section{DAFTAR PUSTAKA}

Ayuningtyas, I., Fadhilah, M. A., \& Arifin, R. W. (2018). Media Pembelajaran Mengenal Hewan Dalam Bahasa Inggris Berbasis Multimedia Interaktif. 6(1), 85-94.

Fadallah, M. F., \& Rosyida, S. (2018). Program Pemesanan Percetakan Berorientasi Objek dengan Pemodelan Unified Modeling Language. AMIK BSI Bekasi, 8, 61-70. http://jurnal.uinsu.ac.id/index.php/algoritma/arti cle/download/3148/1871

Febiharsa, D., Sudana, I. M., \& Hudallah, N. (2018). Uji Fungsionalitas (BlackBox Testing) Sistem Informasi Lembaga Sertifikasi Profesi (SILSP) Batik Dengan AppPerfect Web Test Dan Uji Pengguna. JOINED Journal, 1(2), 117-126. https://doi.org/10.31331/joined.v1i2.752

Gunadi, G. (2020). Rancang Bangun Aplikasi Media Pembelajaran Mengenal Nama Hewan Dalam Dua Bahasa Berbasis Android Menggunakan Thunkable.

Open Handset Alliance. (2009). Android Overview. http://www.openhandsetalliance.com/android_o verview.html

Raharjo, S. (2019). THUNKABLE SECRET: Panduan Lengkap Membuat Aplikasi Android Dalam Hitungan Menit.

Surasmi, W. A. (2016). Pemanfaatan Multimedia untuk Mendukung Kualitas Pembelajaran. Temu Ilmiah Nasional Guru (TING) VIII, November, 593-607-Halaman 597. wuwuh@ut.ac.id 